\title{
The Carabus fauna of Israel - updated identification key, faunistics, and habitats (Coleoptera: Carabidae)
}

\author{
Thorsten Assmann', Jörn Buse', Claudia Drees', Ariel-Leib-Leonid Friedman², \\ Tal Levanony', Andrea Matern', Anika Timm' \& David W. Wrase ${ }^{3}$
}

I Institute of Ecology and Environmental Chemistry, Leuphana University of Lüneburg, Germany 2 Department of Zoology, Tel Aviv University, Israel 3 Berlin, Germany

Corresponding author: Thorsten Assmann (assmann@uni-lueneburg.de)

Academic editor: Terry Erwin | Received 19 May 2008 | Accepted 1 July 2008 | Published 7 July 2008

Citation: Assmann T, Buse J, Drees C, Friedman A-L-L, Levanony T, Matern A, Timm A, Wrase DW (2008) The Carabus fauna of Israel - updated identification key, faunistics, and habitats (Coleoptera: Carabidae). ZooKeys 1: 9-22. doi: $10.3897 /$ zookeys. 1.13

\begin{abstract}
This key to the Carabus species of Israel is an updated identification key with notes on the distribution and habitats of the species. Substantial additions, corrections and taxonomic changes on the Carabus fauna of the Middle East generated the need of an update of the knowledge of the genus Carabus in Israel. The classification and the identification of sibling taxa of the subgenus Lamprostus are still a problem: A zone of sympatry supports the species status of both $C$. sidonius and $C$. hemprichi. The lack of any evidence of sympatry for the taxa in species rank of the $C$. syrus group and their variability of the exoskeleton (mentum tooth, tip of aedeagus) requires further systematic and taxonomic studies.
\end{abstract}

\section{Keywords}

Carabus, Lamprostus, identification key, faunistical records, habitat characteristics, Israel

\section{Introduction}

Despite the fact that Israel is a small country (about $22,000 \mathrm{~km}^{2}$ ), it displays an enormous ecological diversity originating from its peculiar biogeographic location in south-western Asia and its great physical variety (Furth, 1975; Por, 1975; Yom-Tov \& Tchernov, 1988): It links the desert Sahara-Arabia belt, the Mediterranean region and the high Asian mountains. The ground beetle genus Carabus with its preference for humid habitats reaches its southern distribution limit in Israel, and only some species are distributed there (cf. Bousquet et al., 2003). 
The Carabus fauna of Israel was first described in a fundamental work by Schweiger (1970). Substantial additions, corrections and taxonomic changes were made by Kleinfeld \& Rapuzzi (2004) and Deuve (2004; 2005) in the last years. Additional records of some species demonstrate the need of an update of our knowledge on the genus Carabus in Israel. Moreover, the increasing interest in the conservation biology, ecology, evolutionary biology and faunistics of ground beetles in Israel (Bar, 1978; Chikatunov et al., 2006; Chikatunov et al., 1999; 2004; Finkel et al., 2002; Mienis, 1978a; 1978b; 1978c; 1978d; 1988; Pavliček \& Nevo, 1996) demands a new identification key and a short synopsis of the present day knowledge of the distribution, faunistics and habitats of Israeli Carabus species. The taxonomic confusion in this group prevents us from presenting a final identification key. However, we hope that this short overview stimulates further studies to solve some systematic problems of the Carabus fauna of the Middle East.

\section{Material and methods}

The Carabus collection of The National Collections of Natural History of the Tel Aviv University and material from Upper and Lower Galilee, Carmel Ridge, Samaria (incl. Gilboa Mountains), Judea, Negev, Golan Heights and Mount Hermon collected by Anika Timm (Lüneburg), David W. Wrase (Berlin), Peer Schnitter (Halle) and Thorsten Assmann (Bleckede) were studied (altogether about 800 specimens). The relevant literature on Carabus species from Israel and neighbouring countries was evaluated (Alfieri, 1976; Bousquet et al., 2003; Casale \& Vigna Taglianti, 1999; Deuve, 2004a; 2005; Kleinfeld \& Rapuzzi, 2004; Schweiger, 1970).

Nomenclature of vegetation types for a characterisation of the habitats follows Danin (1988).

Total body length (BL) is measured from the tip of the mandibles to the apex of the elytra as the maximum linear distance.

Line drawings were prepared using a drawing tube attached to a Leica MZ 95 stereobinocular microscope. Dissections were made with standard techniques; genitalia were preserved in euparal or in polyvinylpyrrolidon containing mixture on acetate labels (Lompe, 1989) or without embedding in dried condition.

The aim of this study is not a revision of the subspecific taxa. The classifications given by various authors are strikingly different (e.g. Brežina, 1999; Deuve, 2004b; Kleinfeld \& Rapuzzi, 2004). The listed subspecies follow the Palaearctic Catalogue (Bousquet et al., 2003) and Deuve (2004a; 2004b; 2005).

\section{Identification key with notes on distribution and habitats of the species}

The members of the genus Carabus are easily recognizable by the lack of a typical antennal cleaner, posterior coxae contiguous in midline of body, mandibles not transversally furrowed, and third antennal segment without keel. Moreover, the species living 
in Israel are characterized by their body size $(\mathrm{BL}>15 \mathrm{~mm})$ and entirely black colour (without any spots or markings or metallic luster). For a general characterisation of ground beetles see Trautner \& Geigenmüller (1987) and Ball (2001).

1 (15) Pronotum without marginal setiferous pores (Fig. 1a, b, c) 2

2 (3) Labrum divided into three lobes (Fig. 2). Elytra with or without punctuation and granulation, habitus variable. BL: $25-36 \mathrm{~mm}$. An eurytopic species in woodlands (Fig. 15), forests, batha (open and semi-open habitats, Fig. 16), arable land, dunes (Fig. 17), steppe and desert-like, overgrazed, semi-arid habitats of the northern Negev (Fig. 18), up to $1200 \mathrm{~m}$ above sea level. In northern and central Israel southwards to the northern Negev south of Be' er Sheva (e.g. Noqdim Plateau).' Fig. 1a, 7a and 8.

C. (Procrustes) impressus Klug, 1832; in Israel: ssp. carmelita Lapouge, 1907 ssp. palaestinus Lapouge, 1907 ssp. hybridus Ganglbauer, 1887 ssp. negevensis Schweiger, 1970
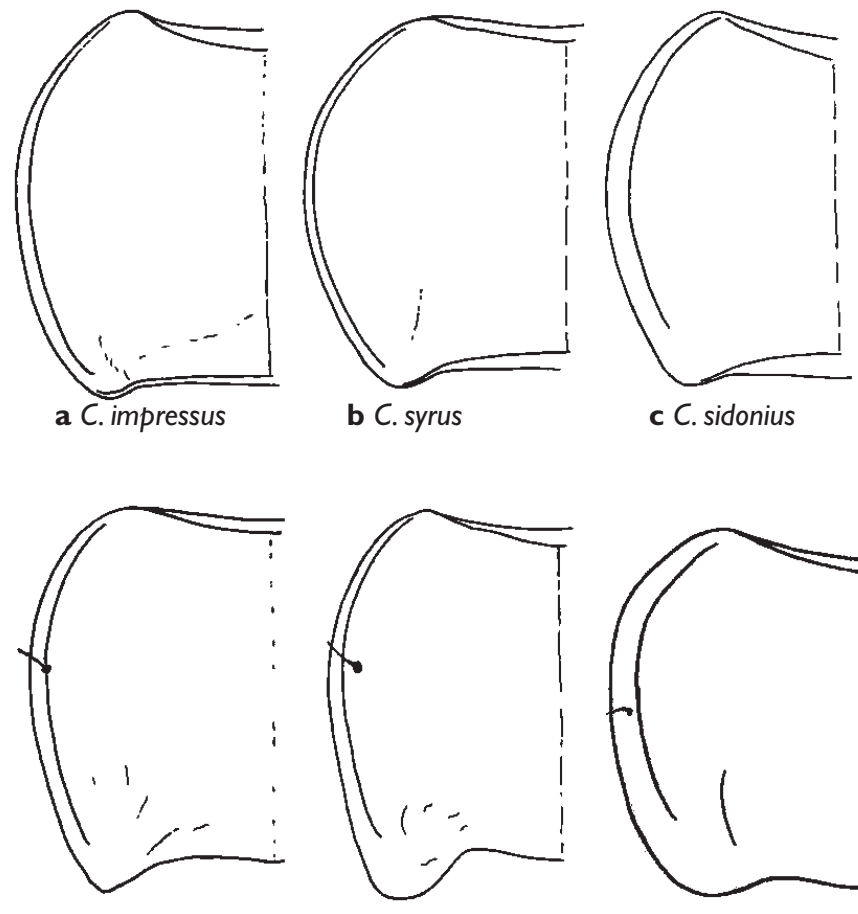

d C. rumelicus

e C. phoenix

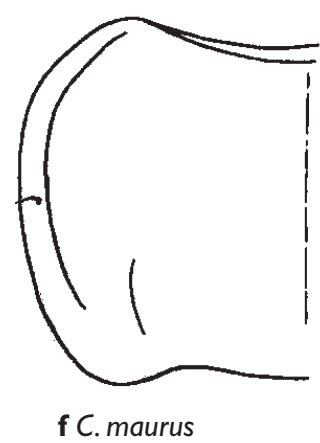

Fig. I. Pronotum without (a, b, c) and with (d, e, f) marginal setiferous pores.

I All records of Carabus specimens from the Sinai Peninsula may refer to this species (cf. Alfieri 1976; cf. Schweiger 1970). 
3 (2) Labrum divided into two lobes (Fig. 2) ................................................. 4

4 (5) Larger in size (BL: $37-44 \mathrm{~mm}$ ). Head and pronotum rugously wrinkled. Protarsus in male not dilated. Last segment of maxillary palpi triangular or axeshaped. In open and semi-open habitats (up to $1600 \mathrm{~m}$ above sea level). Exclusively in the north (Mount Hermon, Golan Heights, Upper Galilee) and very rare. Fig. $7 \mathrm{~b}$ and 9

C. (Procerus) syriacus Kollar, 1843

in Israel only ssp. galilaeus Schweiger, 1970

5 (4) Smaller in size (BL: $<37 \mathrm{~mm}$ ), if larger then at least head and pronotum smooth, not rugously wrinkled. Three segments of protarsus in male dilated. Last segment of maxillary palpus not triangular or axe-shaped .................... 6

6 (7) Elytral sculpture with punctures and striae. Slender species. BL: 25-36 mm. In woodlands (Fig. 15), forests, and batha (Fig. 16), not in arable land ( -500 to $2000 \mathrm{~m}$ above sea level, Fig. 19). In the north (Mount Hermon, Golan Heights, Upper and Lower Galilee). Fig. 7c and 10

C. (Chaetomelas) piochardi Géhin, 1884 in Israel: ssp. labruleriei Géhin, 1884 ssp. pinguis Lapouge, 1914

7 (6) Elytron without punctures or striae, smooth. Wider species........................ 8

8 (9) Elytron less rounded in lateral view (Fig. 3). Pronotum wider (Fig. 1b) .... 11

9 (10) Elytron more rounded in lateral view (Fig. 3). Pronotum slender (Fig. 1c)....

11 (12) Tooth of mentum broad, tip truncate (Fig. 4a). Median lobe of aedeagus rounded at apex (Fig. 7d). BL: 32-39 mm. Mainly in open and semi-open habitats (especially batha, Fig. 16), rarely in woodlands or forests (from 200 $\mathrm{m}$ below sea level to $1400 \mathrm{~m}$ above sea level, Fig. 15). From Mount Hermon and Golan Heights to Upper Galilee (Mt. Meron, first finding in 2005). Fig. $1 \mathrm{~b}, 2,3$ and 11

C. (Lamprostus) syrus Roeschke, 1898 in Israel only ssp. cheikensis Deuve, 1992

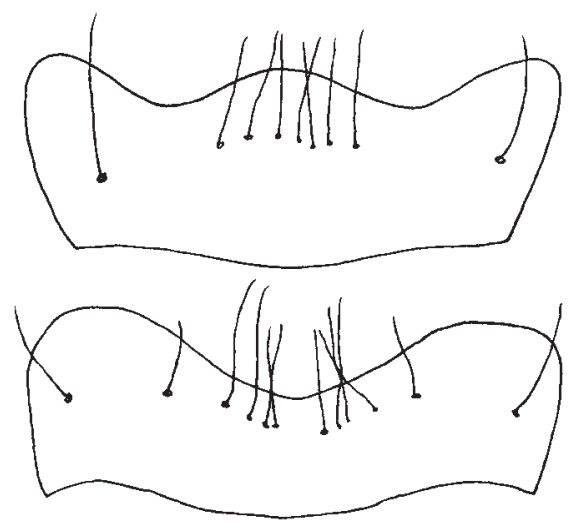

Fig. 2. Labrum divided into three lobes (above: $C$. impressus) and two lobes (below: C. syrus).

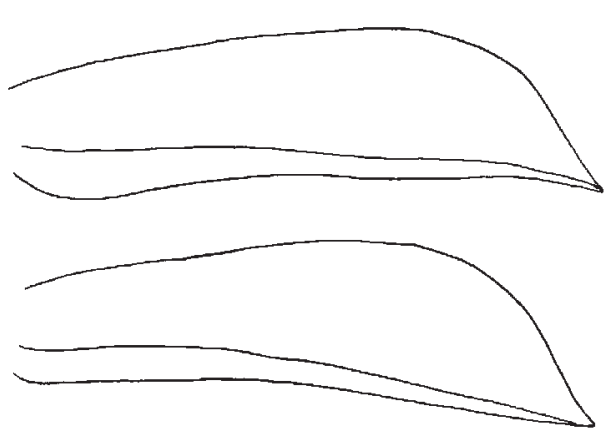

Fig. 3. Elytron in lateral view, less rounded (above: C. syrus) and more rounded (below: C. sidonius). 
12 (11) Tooth of mentum sharpened (Fig. 4b). Median lobe of aedeagus sharpened at apex (Fig. 7e). BL: 32-37 mm. Distribution area still poorly known, described from Lebanon. Listed by Schweiger \& Rapuzzi (2004) from northeastern Israel ..................................... (Lamprostus) lecordieri Deuve, 1992

Note: C. lecordieri was degraded as a subspecies of C. syrus by Kleinfeld \& Rapuzzi (2004), but the species status was re-established by Deuve (2005). Deuve (2004b) treated the taxon as a subspecies of C. syrus. Some specimens from Israel cannot be classified as one of the species due to variability of the mentum tooth and small differences of the aedeagus.

13 (14) Hind angles of pronotum rounded, a little bit more pronounced, very similar to its sister species (C. hemprichi). Apical part of aedeagus deflexed, narrow and more distinctly set off (Fig. 7f). BL: 31-35 mm. In woodlands (Fig. 15), forests, and batha (up to $1200 \mathrm{~m}$ above sea level, Fig. 16). Northern and central Israel, southwards up to Jerusalem. Fig. 1c, 3, 4c and 12

C. (Lamprostus) sidonius Lapouge, 1907 in Israel: ssp. elonensis Schweiger, 1970 ssp. cheikhermonensis Deuve, 1992

14 (13) Hind angles of pronotum rounded, only slightly prolongate. Apical part of aedeagus not distinctly deflexed, wider and not distinctly set off (Fig. 7g). BL: 31$37 \mathrm{~mm}$. In woodlands, batha and arable fields. In north-eastern Israel (Mount Hermon and Golan Heights) C. (Lamprostus) hemprichi Dejean, 1826 in Israel only damascenus Lapouge, 1924

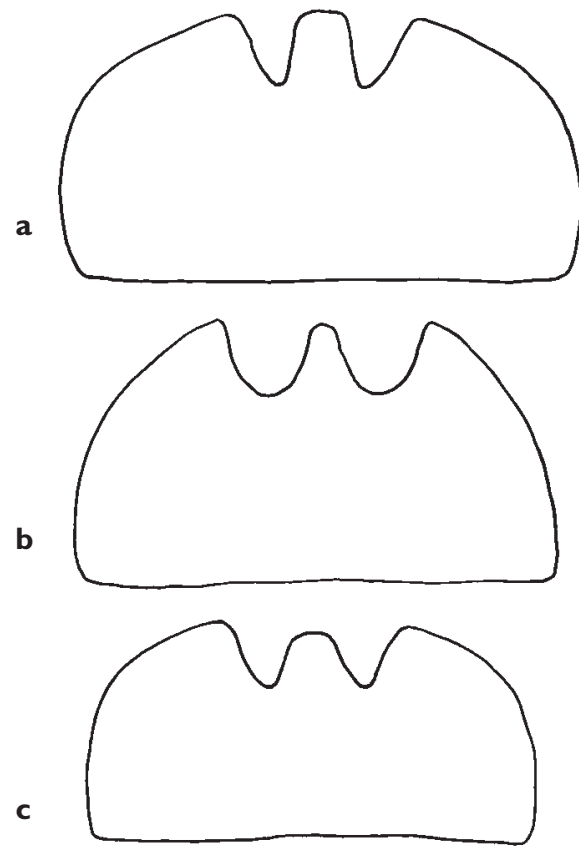

Fig. 4. Mentum of Lamprostus species (a: C. syrus; b: C. lacordieri; c: C. sidonius).
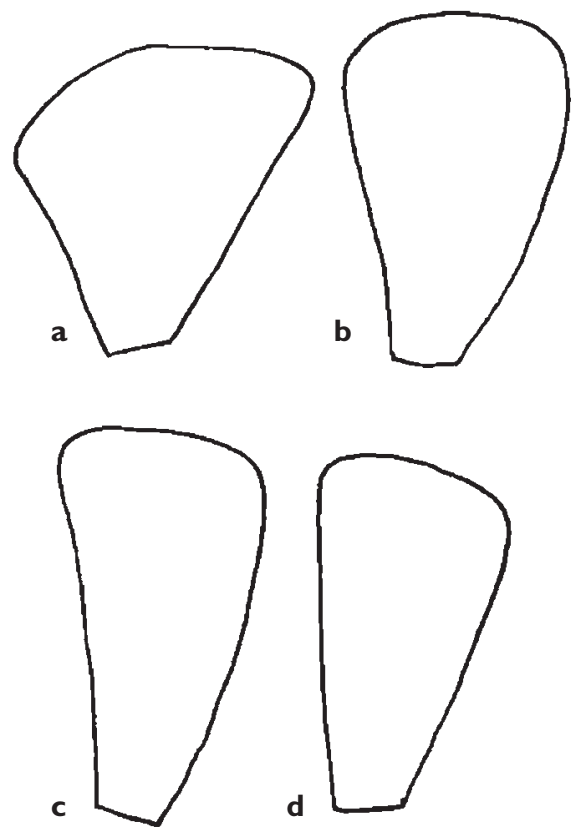

Fig. 5. Last segment of maxillary palpi (a, b: $C$. rumelicus; c, d: C. maurus; a, c: male; b, d: female). 

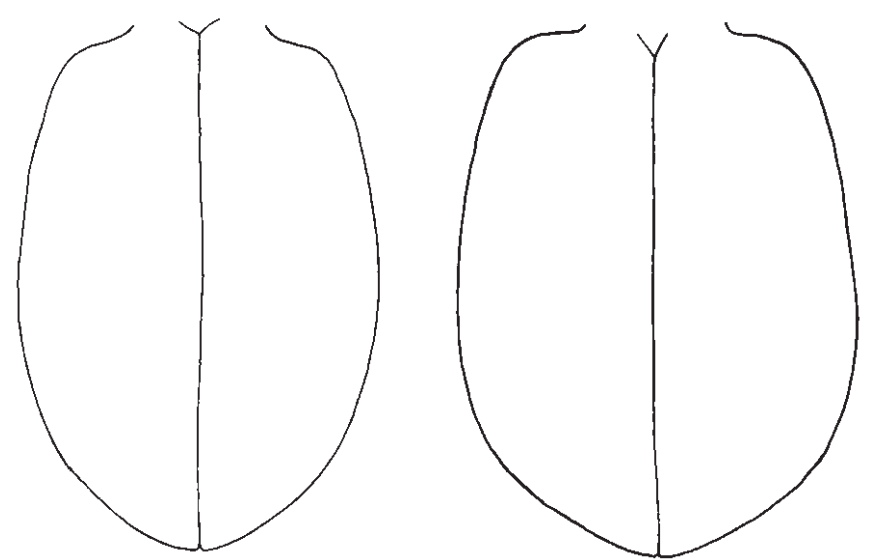

Fig. 6. Shoulder of elytron rounded (left: C. phoenix) and angulate (right: C. maurus).
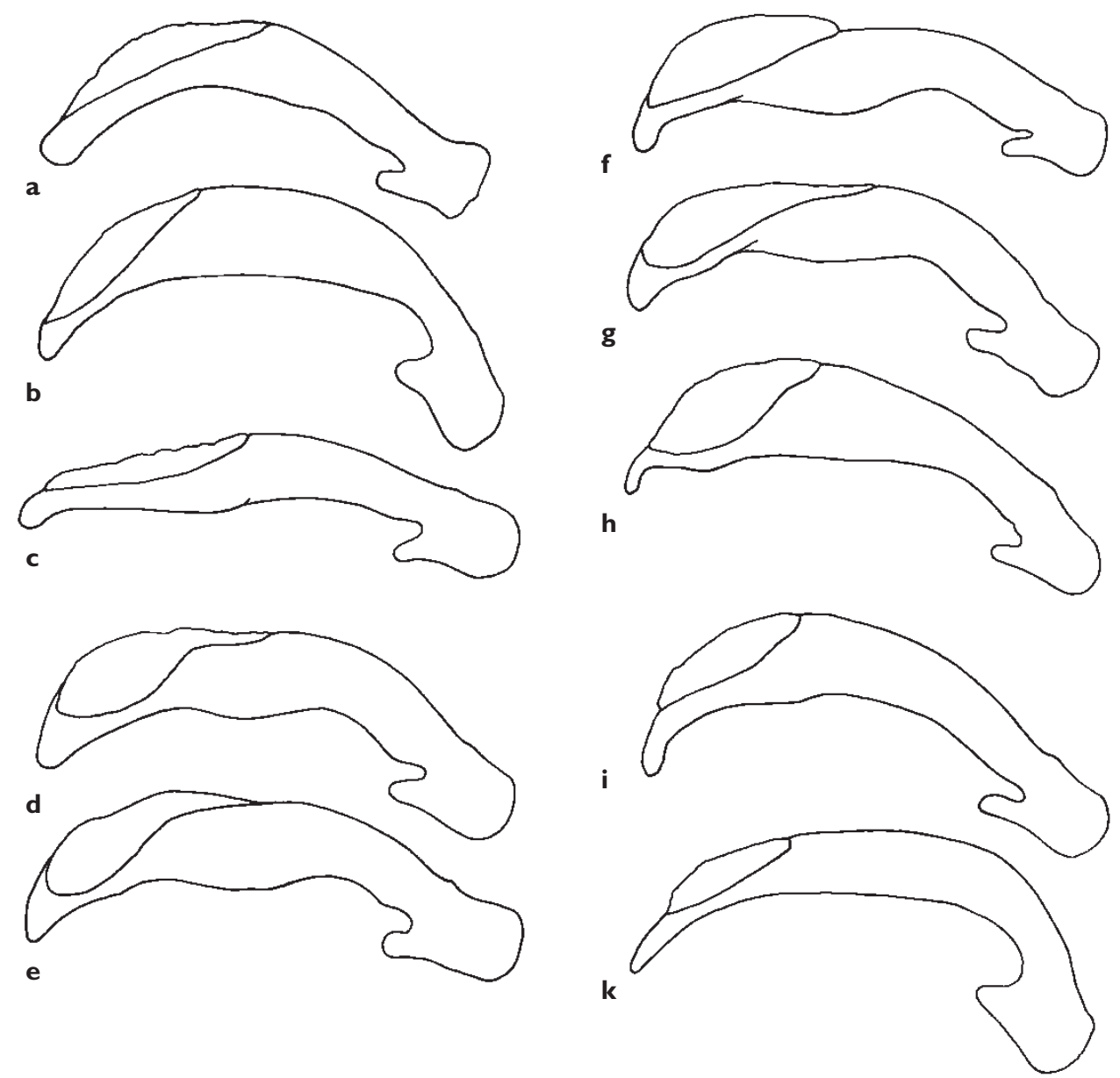

Fig. 7. Aedeagus of C. impressus (a), C. syriacus (b), C. piochardi (c), C. syrus (d), C. lecordieri (e), C. sidonius (f), C. hemprichi (g), C. rumelicus (h), C. phoenix (i), and C. maurus (k). 
Note: A zone of sympatry between $C$. hemprichi and $C$. sidonius in Lebanon led Deuve (2004) to consider both taxa as valid species. In previous publications these taxa were ranked as subspecies of $C$. hemprichi. The distinction of both species is extremely difficult. Moreover, in the last years two additional sibling species of the subgenus Lamprostus were described from Lebanon.

15 (1) Pronotum with marginal setiferous pores (if seta broken, the pupillate insertion is visible) (Fig. 1d, e, f).....

16 (17) Last segment of maxillary palpus in males triangular or axe-shaped (Fig. 5a). BL: $17-20 \mathrm{~mm}$. In montane and subalpine altitudes of Mount Hermon (semiopen woodlands with Quercus libani and tragacanth vegetation, pastures, Fig. 19). Fig. 1d, 5b, 7h and 13 ...... C. (Tomocarabus) rumelicus Chaudoir, 1867 in Israel only ssp. syriensis Breuning, 1943

17 (16) Last segment of maxillary palpus in males more elongate, slightly dilated (Fig. 5c)

18 (19) Submentum thickened. Hind angles of pronotum prolongate (Fig. 1e). Shoulder of elytra rounded (Fig. 6a). BL: 17-25 mm. In Israel exclusively known from Upper Galilee (Mt. Meron), in woodlands (Fig. 15). Fig. 13 .... C. (Archicarabus) phoenix Lapouge, 1924

19 (20) Submentum not thickened. Hind angles of pronotum more rounded (Fig. 1f). Shoulder of elytra angulate (Fig. 6b). BL: $15-20 \mathrm{~mm}$. In montane and subalpine altitudes of Mount Hermon (semi-open woodlands with Quercus libani and tragacanth vegetation). Fig. $5 \mathrm{c}, 5 \mathrm{~d}$ and $7 \mathrm{k}$.

C. (Mimocarabus) maurus Adams, 1817 in Israel only ssp. hermonensis Schweiger, 1970

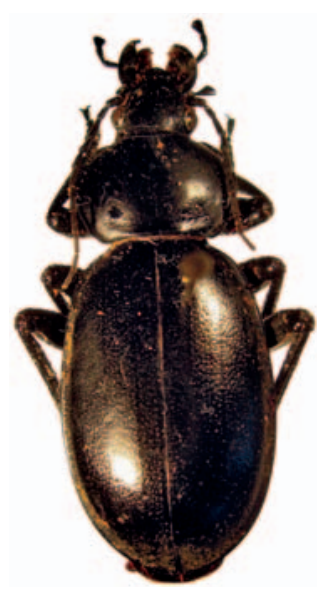

Fig. 8. Carabus impressus (Negev).

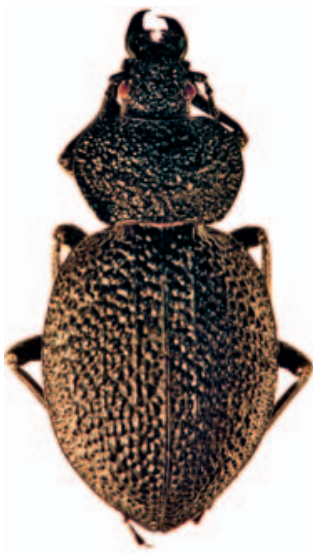

Fig. 9. Carabus syriacus (Mount Meron).

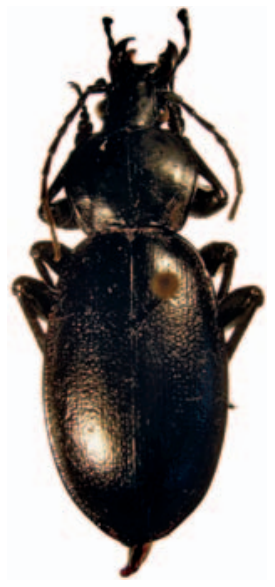

Fig. 10. Carabus piochardi (Mount Meron).

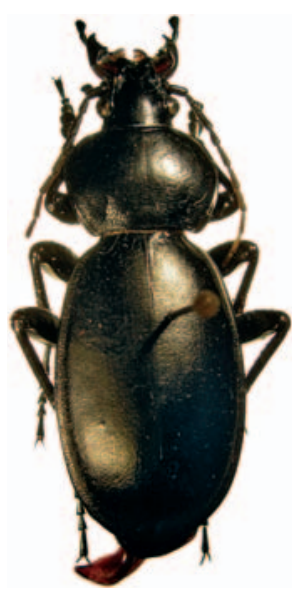

Fig. I I. Carabus syrus (Mount Meron). 


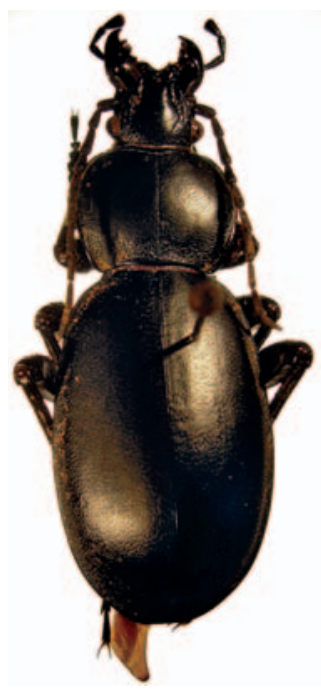

Fig. 12. Carabus sidonius (Mount Meron).

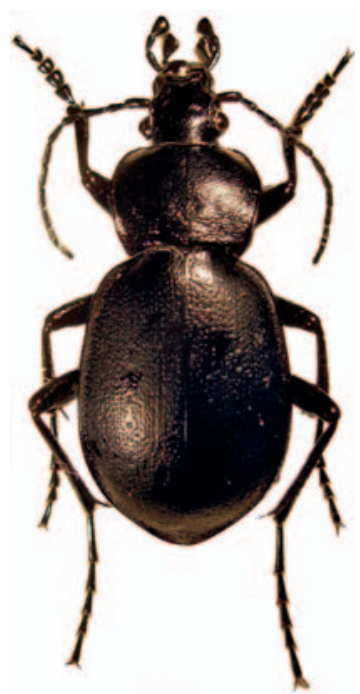

Fig. 13. Carabus rumelicus (Mount Hermon).

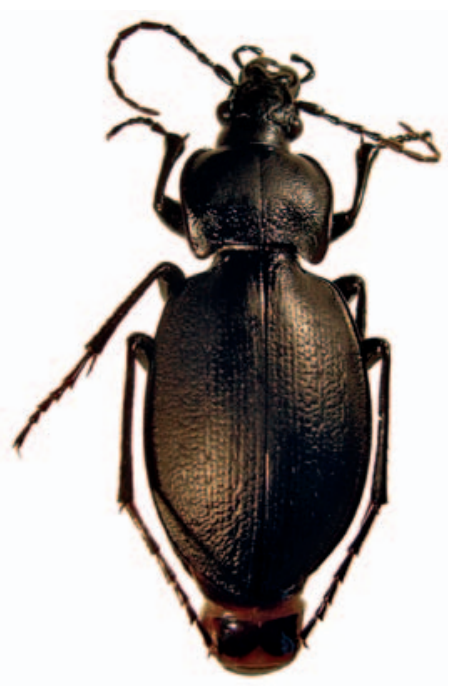

Fig. I4. Carabus phoenix (Mount Meron).

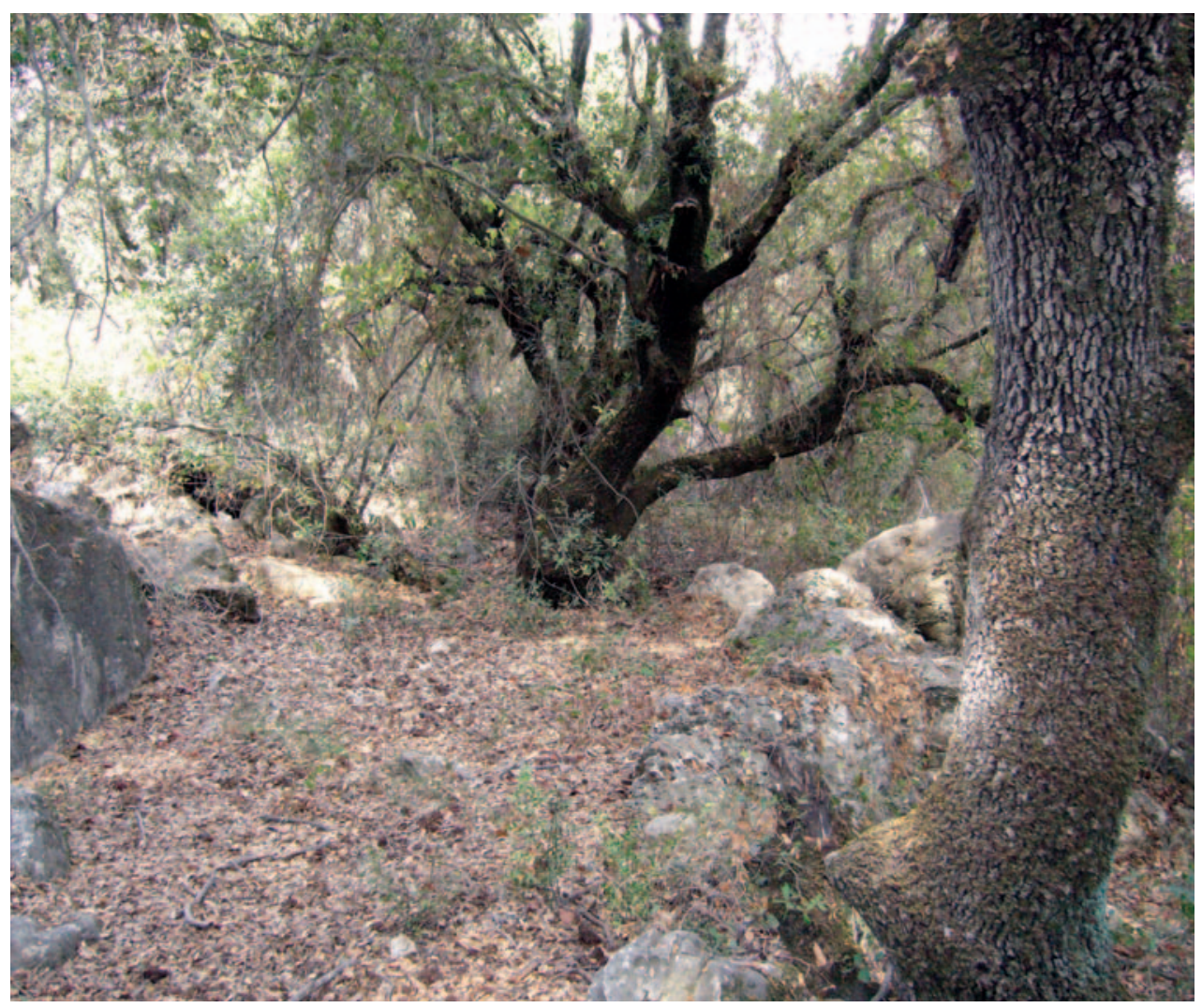

Fig. 15. Quercus calliprinos dominated woodland (Ya'ar Bar'am). Habitat of C. impressus, C. piochardi, C. syrus, C. sidonius, and C. phoenix. 


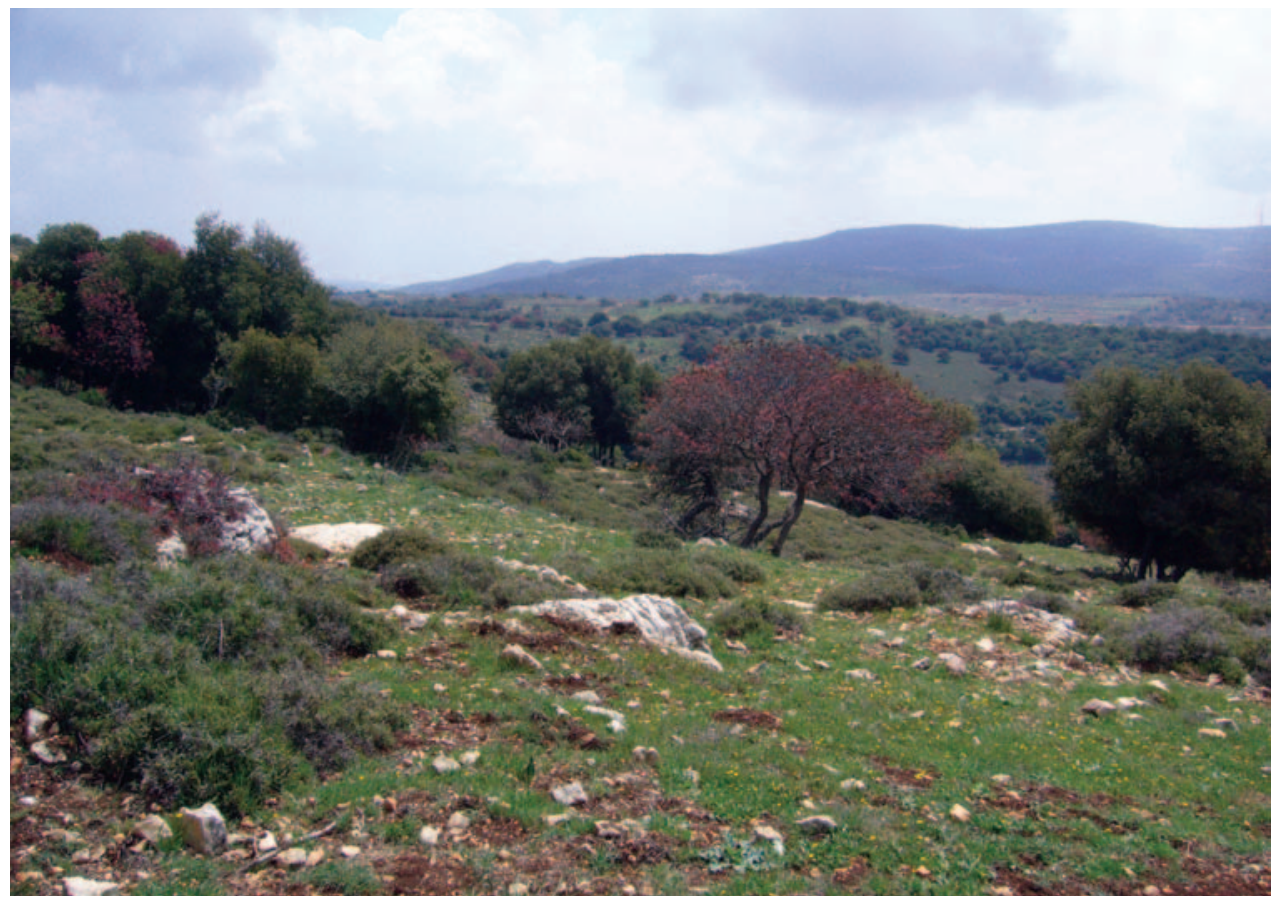

Fig. I6. Batha (Mount Meron). Habitat of C. impressus, C. piochardi, C. syrus, and C. sidonius.

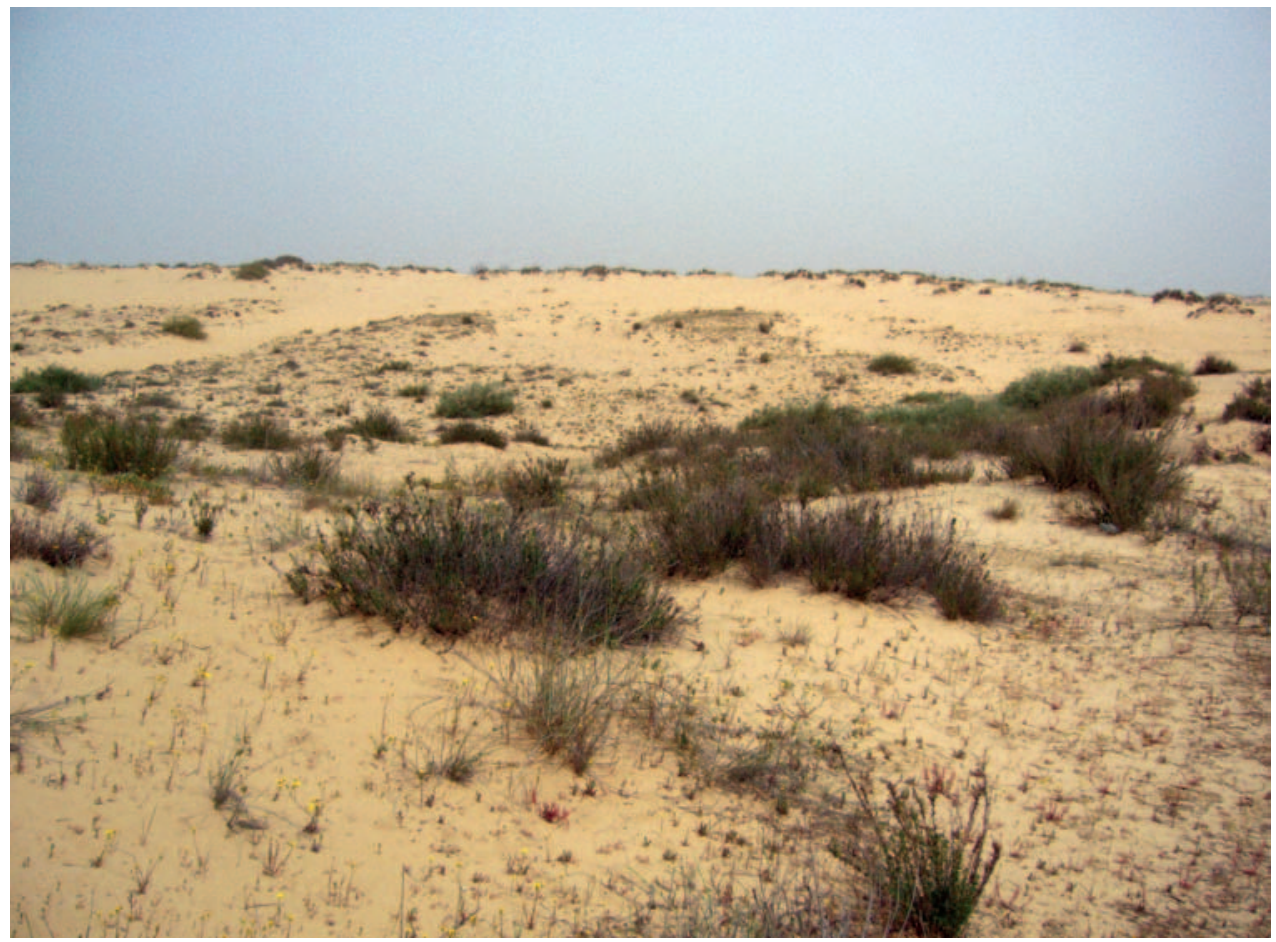

Fig. 17. Dune habitat (south of Ashdod). Habitat of C. impressus. 


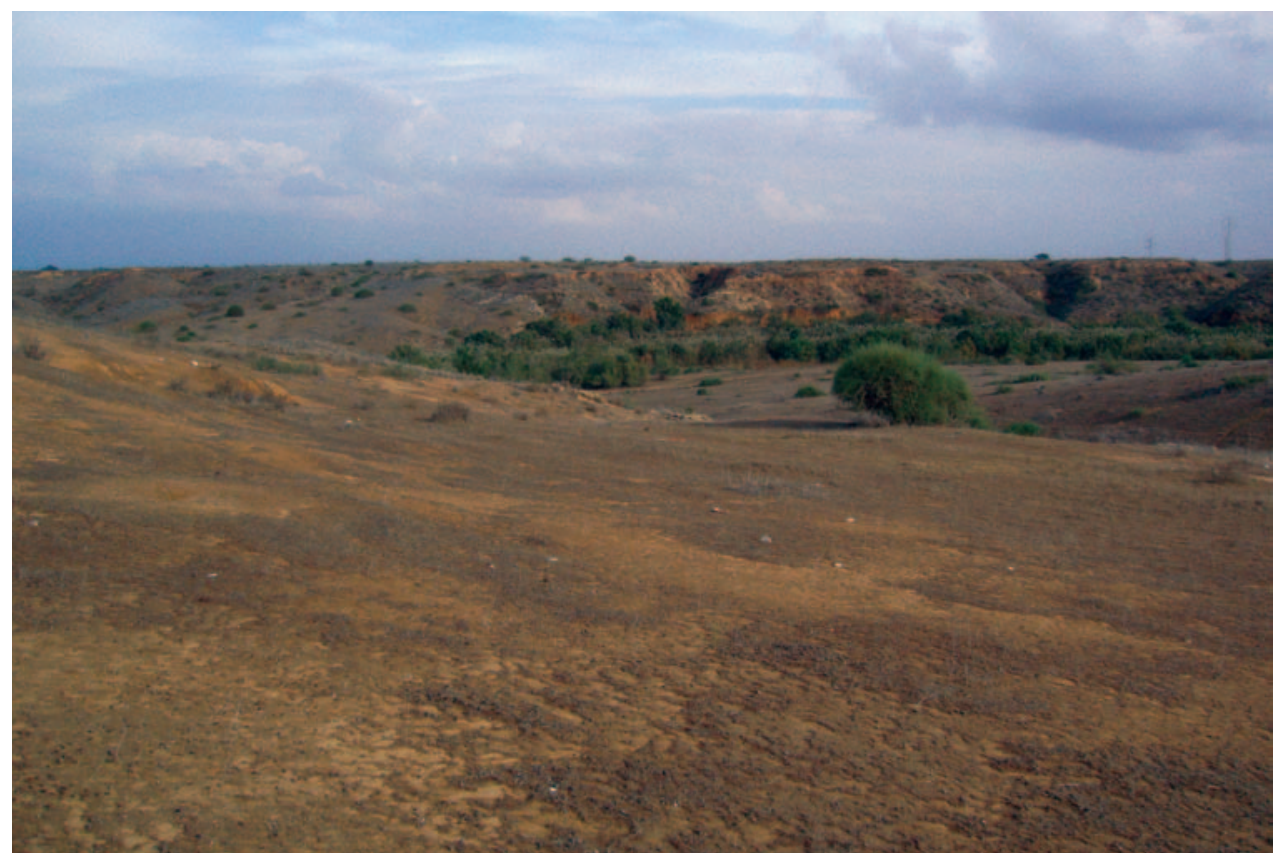

Fig. 18. Steppe habitat (west of Be'er Sheva). Habitat of C. impressus.

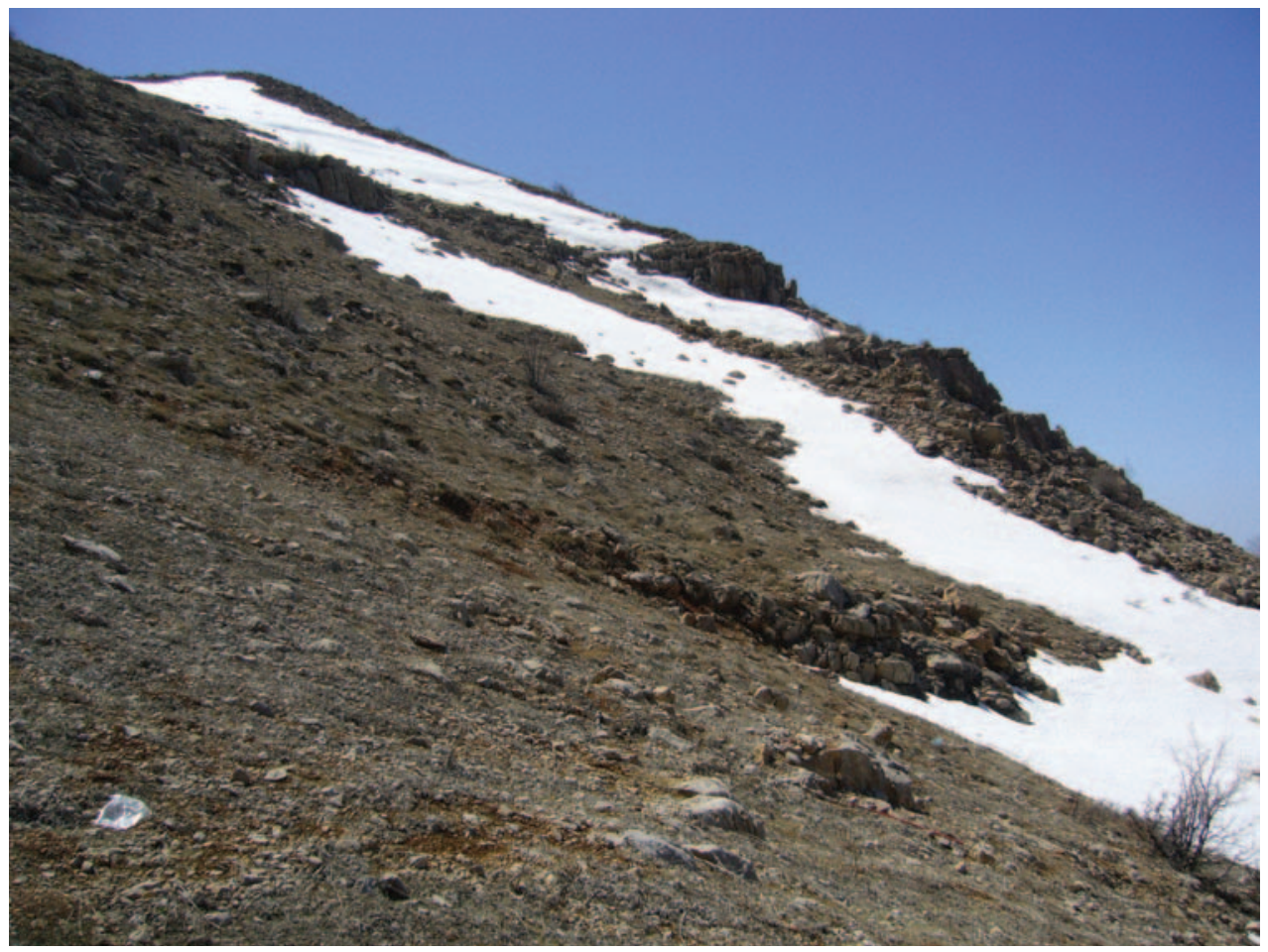

Fig. 19. Montane to subalpine pasture (Mount Hermon). Habitat of C. piochardi and C. rumelicus. 


\section{Discussion}

Ten species of the genus Carabus are known from Israel. The presence of $C$. phoenix in Israel - first records known from the surrounding of Sasa in Upper Galilee (Kleinfeld \& Rapuzzi, 2004) - can be confirmed by several records from the Meron area (Upper Galilee, cf. Timm et al., 2008) ${ }^{2}$. At several locations in Galilee (including a site close to the Sea of Galilee, about $200 \mathrm{~m}$ below sea level) we detected Carabus syrus populations. The previously known distribution area in Israel covers the Golan Heights, parts of the Mount Hermon and the Upper Jordan Valley close to Qiryat Shemona (Schweiger \& Rapuzzi, 1970). We believe that larger parts of Galilee (including Lower Galilee), Golan Heights and Judean Foothills are still under-represented in faunistical studies. Therefore it seems most likely that additional populations and perhaps species can be detected. From Jordan and Lebanon new species of the subgenus Lamprostus were already described in the last years (C. pseudopinguis Heinz, 2000; C. lecordieri Deuve, 1992; C. rostandianus Deuve, 2005; cf. Deuve, 2005; Heinz \& Staven, 2000).

Despite the still incomplete faunistic inventory of Israel, the records of C. syriacus seem to decline, especially in the last decades. Coleopterists, also those collecting mainly in the northern parts of Israel, have not found this largest Carabus species in the Middle East for many years (e.g. Rittner, personal communication). Urbanization, habitat fragmentation and large-scale changes of land use (especially the transformation of natural and semi-natural habitats, e.g. sclerophyllous woodlands and batha, to pine stands and arable fields) might be a reason for this decline. Species of the subgenus Procerus show a remarkable decline not only at the southern limit of their distribution area but also in Europe: C. gigas Creutzer, 1799 was once distributed in Styria and Carinthia. At present the species is extinct in Austria (Paill, personal communication), in Slovenia the species is still occurring, but clearly declining (Drovenik, personal communication; Turin et al., 2003). A similar decline seems to occur in some places in Italy (Brandmayr and Casale, personal communication). - If one or several populations are rediscovered, an action plan to conserve the relict populations at the most southern limit of this species (and subgenus) will have to be developed.

A clear problem for identification are the sibling taxa of two Lamprostus groups: The characters given in the literature to separate $C$. hemprichi from $C$. sidonius and $C$. syrus from $C$. lacordieri show a remarkable variability within and between populations; this is true for both the mentum tooth and the apex of the median lobe of aedeagus. Sometimes it is impossible to classify some specimens exclusively from the exoskeleton. While a zone of sympatry is known for $C$. hemprichi und C. sidonius in Lebanon, any evidence of sympatry is still lacking for the members of the C. syrus group (including C. lacordieri, C. pseudopinguis and C. rostandianus).

The results of Pavliček \& Nevo (1996) on C. sidonius demonstrated a small-scaled genetic differentiation, similar to some other Carabus species (Assmann, 2003; Assmann

2 Records from Sasa are not considered in the distribution map of C. phoenix given by Kleinfeld \& Rapuzzi (2004). 
\& Weber, 1997). The morphological differentiation (from eye inspection) reflects this strong geographic differentiation on another level and should encourage us to study the species complexes morphometrically in order to solve the taxonomic problems (but for this approach still more material is necessary than is available at the moment).

In general one has to keep in mind that differences in the aedeagus, especially those of the apex (and not of the internal sac) of this organ, do not seem to be useful to classify taxa at the species level (see for a detailed discussion: Assmann et al., 2008). The taxa C. violaceus violaceus Linné, 1758 and C. v. purpurascens Fabricius, 1787 of the subgenus Megodontus can be easily distinguished by different forms of the aedeagus tip (and by lack or presence of striae on the elytra). But both taxa form several broad hybrid zones in north-western Central Europe (Assmann \& Schnauder, 1998). An excessive gene flow is documented also by molecular techniques (allozymes and mtDNA haplotypes; Eisenacher et al., in prep.). In the light of these results the species rank of some taxa of the C. syrus group should be critically reconsidered.

\section{Acknowledgements}

We would like to thank Dr Thierry Deuve, Museum National d'Histoire Naturelle (Department de Systématique, Paris), for his help in identification and verification of some of our determinations. We are indebted to the curator of the Coleoptera collection Prof Dr Vladimir Chikatunov, and to the chief curator Dr Amnon Friedberg, who enabled us to study material from The National Collections of Natural History of the Tel Aviv University and to borrow specimens from this collection. Finally, we thank Uta Gebert (Berlin) for the photograph of Carabus syriacus.

\section{Literature}

Alfieri A (1976) The Coleoptera of Egypt. Mémoires de la Société Entomologique de Égypte 5: $1-361$.

Assmann T (2003) Biology and ecology. In: Turin H, Penev L, Casale A (Eds) The genus Carabus in Europe: A synthesis. Pensoft Publishers \& European Invertebrate Survey, SofiaMoscow \& Leiden, 287-305.

Assmann T, Schnauder C (1998) Morphometrische Untersuchungen an einer Kontaktzone zwischen Carabus (Megodontus) violaceus und purpurascens (Coleoptera, Carabidae) in Südwest-Niedersachsen. Osnabrücker Naturwissenschaftliche Mitteilungen 24: 111-138.

Assmann T, Buse J, Drees C, Habel J, Härdtle W, Matern A, von Oheimb A, Schuldt A, Wrase DW (2008) From Latreille to DNA systematics - towards a modern synthesis for carabidology. In: Penev LD, Erwin T, Assmann T (Eds) Back to the roots and back to the future? Towards a new synthesis amongst taxonomic, ecological and biogeographical approaches in carabidology. Pensoft Publishers, Sofia-Moscow, 41-76. 
Assmann T, Weber F (1997) On the allozyme differentiation of Carabus punctatoauratus Germar (Coleoptera, Carabidae). Journal of Zoological Systematics and Evolutionary Research 35: 33-43.

Brežina B (1999) World catalogue of the genus Carabus L. Pensoft Publishers, Sofia-Moscow, $170 \mathrm{pp}$.

Ball GE (2001) Carabidae Latreille, 1810. In: Arnett RS, Thomas MC (Eds) American beetles, volume 1: Archostemata, Myxophaga, Adephaga, Polyphaga: Staphyliniformia. CRC Press, Boca Raton, London, New York, Washington, D.C., 32-132.

Bar Z (1978) Additional records of land snail predation by carabid beetles in Israel. Levantina 15: 167.

Bousquet Y, Brežina B, Davies A, Farkac J, Smetana A (2003) Tribe Carabini Latreille, 1802. In: Löbl I, Smetana A (Eds) Catalogue of Palaearctic Coleoptera Vol. 1: Archostemata, Myxophaga, Adephaga. Apollo Books, Stenstrup, 118-201.

Casale A, Vigna Taglianti A (1999) Caraboid beetles (excl. Cicindelidae) of Anatolia, and their biogeographical significance (Coleoptera, Caraboidea). Biogeographia 20: 277-406.

Chikatunov V, Kravchenko VD, Müller GC (2006) Carabidae (Coleoptera) collected in the Israeli light trap survey and their association with the major phyto-geographical zones of Israel. Esperiana 12: 291-298.

Chikatunov V, Pavliček T, Nevo E (1999) Coleoptera of "Evolution Canyon": Lower Nahal Oren, Mount Carmel, Israel. Pensoft Publishers, Sofia-Moscow, 174 pp.

Chikatunov V, Pavliček T, Nevo E (2004) Coleoptera of "Evolution Canyon” Lower Nahal Oren, Mount Carmel, Israel, Part II. Pensoft Publishers, Sofia-Moscow, 192 pp.

Danin A (1988) Flora and vegetation of Israel and adjacent areas. In: Yom-Tov Y, Tchernov E (Eds) The zoogeography of Israel: the distribution and abundance at a zoogeographical crossroad. Dr W. Junk Publishers, Dordrecht, Boston, Lancaster, 129-158.

Deuve T (2004a) Carabus (Lamprostus) sidonius Lapouge, 1907, bona species, et note sur les Carabes du Liban (Coleoptera, Carabidae). Coléoptères 10: 91-105.

Deuve T (2004b) Illustrated Catalogue of the Genus Carabus of the World (Coleoptera: Carabidae). Pensoft Publishers, Sofia-Moscow, 461 pp.

Deuve T (2005) Un nouveau Carabus L., 1758, du Liban (Coleoptera, Carabidae). Coléoptères 11: $123-128$.

Finkel M, Chikatunov V, Nevo E (2002) Coleoptera of «Evolution Canyon» II: Lower Nahal Keziv, western Upper Galilee, Israel. Pensoft Publishers, Sofia-Moscow, 270 pp.

Furth DG (1975) Israel, a great biogeographic crossroads. Discovery 11 (1): 2-13.

Heinz W, Staven K (2000) Beschreibung einer neuen Subspezies von C. (L.) syrus Roeschke, 1898, aus Jordanien und Bemerkungen zur Nomenklatur und Verbreitung der Carabus (Chaetomelas)-Arten im Nahen Osten. Entomologische Zeitschrift 110: 147-151.

Kleinfeld F, Rapuzzi I (2004) Zur Faunistik der Carabus- und Procerus-Arten im ,Nahen Osten“ (Coleoptera: Carabidae: Carabini). Lambillionea 54, Supplement: 1-72.

Lompe A (1989) Ein bewährtes Einbettungsmittel für Insektenpräparate. In: Lohse GA, Lucht WH (Eds) Die Käfer Mitteleuropas, 1. Supplementband mit Katalogteil. Goecke und Evers, Krefeld, 17-18. 
Mienis HK (1978a) The ground beetle Carabus impressus feeding on the landsnail Cernuella (Microxeromagna) arrouxi. Levantina 13: 142-143.

Mienis HK (1978b) Carabus impressus also feeding on Monacha haifaensis. Levantina 14: 148. Mienis HK (1978c) Carabus impressus also feeding on Xeropicta vestalis joppensis. Levantina 15: 167. Mienis HK (1978d) Additional records of land snail predation by carabid beetles in Israel. Levantina 15: 167.

Mienis HK (1988) Additional records of predation on landsnails by the ground beetle Carabus impressus in Israel. The Conchologists' Newsletter 106: 121-123.

Pavliček T, Nevo E (1996) Genetic divergence in populations of the beetle Carabus hemprichi from microclimatically opposing slopes of "Evolution Canyon": A Mediterranean microsite, Mount Carmel, Israel. Israel Journal of Zoology 42: 403-409.

Por FD (1975) An outline of the zoogeography of the Levant. Zoologica Scripta 4: 5-20.

Schweiger H (1970) The genus Carabus in Israel. Israel Journal of Entomology 5: 21-55.

Timm A, Dayan D, Levanony T, Wrase D, Assmann T (2008) Towards combined methods for recording ground beetles: Pitfall traps, hand picking and sifting in Mediterranean habitats of Israel. In: Penev LD, Erwin T, Assmann T (Eds) Back to the roots and back to the future? Towards a new synthesis amongst taxonomic, ecological and biogeographical approaches in carabidology. Pensoft Publishers, Sofia-Moscow, 397-408.

Trautner J, Geigenmüller K (1987) Tiger beetles, ground beetles. Illustrated key to the Cicindelidae and Carabidae of Europe. Margraf, Aichtal, 488 pp.

Turin H, Penev L, Casale A, Arndt E, Assmann T, Makarov KV, Mossakowski D, Szél G, Weber F (2003) Species accounts. In: Turin H, Penev L, Casale A (Eds) The genus Carabus in Europe: A synthesis. Pensoft Publishers \& European Invertebrate Survey, Sofia-Moscow \& Leiden, 151-283.

Yom-Tov Y, Tchernov E (Eds) (1988) The zoogeography of Israel - the distribution and abundance at a zoogeographical crossroad. Dr W. Junk Publishers, Dordrecht, Boston, Lancaster, 616 pp. 